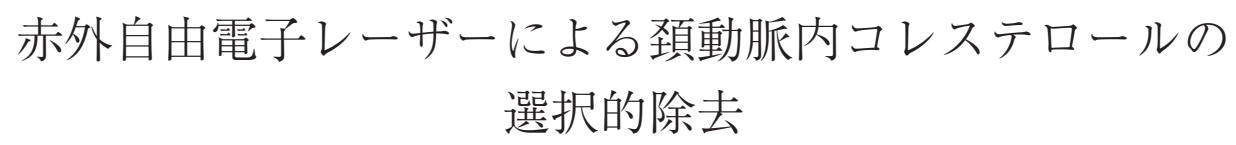

\author{
石井 克典，岩月 幸一*，吉峰 俊樹*，粟津邦男 \\ 大阪大学大学院 工学研究科電子情報エネルギー工学専攻 ( ₹ 573-1028 大阪府枚方市津田山手2-9-5) \\ *大阪大学大学院 医学系研究科臟器制御医学専攻 (广565-0871 大阪府吹田市山田丘2-2)
}

\title{
The Selective Removal of Cholesterol Oleate in the Human Carotid Artery by Infrared Free Electron Lasers
}

\author{
Katsunori ISHII, Kouichi IWATUKI,* Toshiki YOSHIMINE,* and Kunio AWAZU \\ Institute of Free Electron Laser, Department of Electronic, Information Systems and Energy Engineering, \\ Graduate School of Engineering, Osaka University, 2-9-5 Tsuda-Yamate, Hirakata, Osaka 573-0128 \\ *Department of Neurosurgery, Graduate School of Medicine, Osaka University,
}

\author{
2-2 Yamadaoka, Suita, Osaka 565-0871
}

(Received August 7, 2002)

\begin{abstract}
We observed and discussed the effects of Free Electron Laser (FEL) irradiation to cholesterol accumulated in the regions of arteriosclerosis in the human carotid artery, by an Infrared micro spectroscopy (FT-IR). As a result of this study, we found that we could selectively remove cholesterol only without effects to normal parts of the human body, in irradiating $5.75 \mu \mathrm{m}$-FEL that come from a ester bond of cholesterol ester, under the condition that average power is $5 \mathrm{~mW}$, power density is $\sim 16 \mathrm{~W} / \mathrm{cm}^{2}$ and irradiation time is $30 \sim 180 \mathrm{sec}$.
\end{abstract}

Key Words: Free Electron Laser (FEL), Arteriosclerosis, Cholesterol ester, Selective removal

\section{1.はじめに}

我々は，赤外自由電子レーザー(IR-FEL)によって選択 的にコレステロールエステルを除去する可能性を示して きた。これは粥状動脈硬化の主要因であるコレステロー ルエステル(コレステロールとオレイン酸，リノール酸な どの脂肪酸がエステル結合したもの)の，エステル結合の 分子振動に対応した波長 $5.75 \mu \mathrm{m}$ のFELを照射することに より，コレステロールエステルのみが選択的に除去され る現象である。この現象は樕状動脈硬化起因の心筋梗 塞, 狭心症, 脳梗塞等の循環器系疾患の低侵襲的な予防 や治療の可能性を示すもので，IR-FELの医療応用にとっ ての基礎検討として極めて重要である1-7).

そこで本研究では，医療応用への基礎として，ヒトの 粥状動脈硬化部位中のコレステロールをサンプルとして 用いて，正常組織への侵襲度の低い選択的除去可能性 を，IR-FELを用いて検討し，顕微赤外分光法(FT-IR)によ り評価・考察した。

\section{2. in vitro 実験}

2.1 FEL照射サンプル

サンプルには，ヒトの左澒動脈内樕状動脈硬化部位を
用いた. 摘出した動脈内膜から薄く切り出した切片を, 赤外透過用 $\mathrm{BaF}_{2}$ 基板 (直径 $13 \mathrm{~mm}$, 厚さ $1 \mathrm{~mm}$ ) に貼り付け た後乾燥させた。顤動脈サンプルの作成法をFig. 1に示 す.

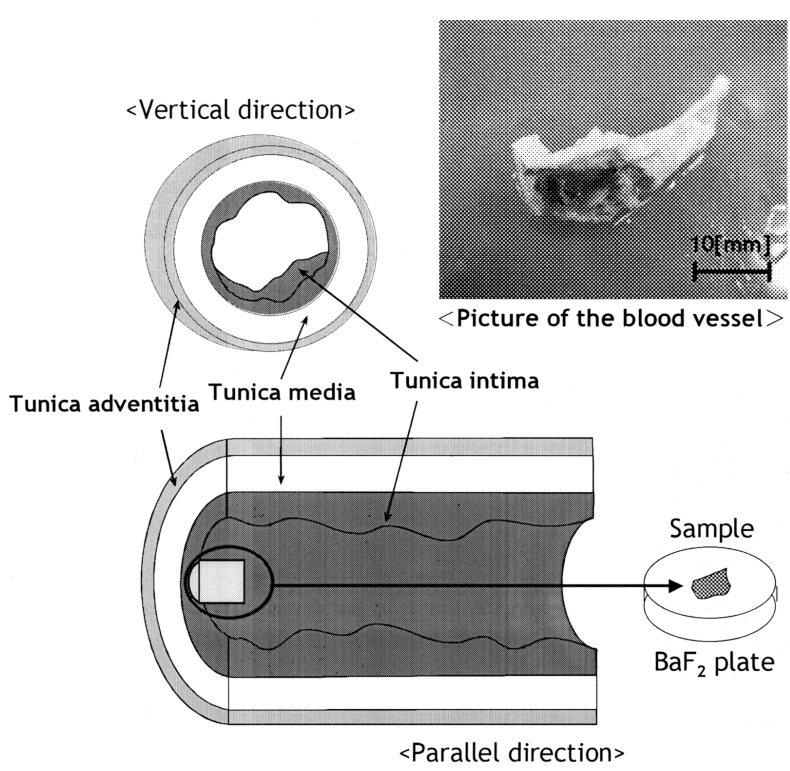

Fig. 1 Cutaway view of the blood vessel in the region of arteriosclerosis. 
2.2 頚動脈内膜赤外吸収スペクトル

ヒトの䅡動脈内膜正常組織についての測定結果をFig. 2 (a)に，继状動脈硬化コレステロール蓄積部位についての

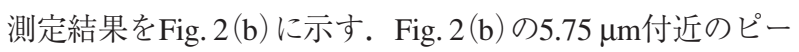
クが, コレステロールエステル特有の分子間伸縮振動に 由来する赤外吸収スペクトルピークである。また, 生体 組織の蛋白質中に多く見られるアミドI結合のピークは $6.06 \mu \mathrm{m}$ 付近, アミドII結合のピークは6.45 $\mu \mathrm{m}$ 付近に顕著 に見られる8).

\section{3 実験方法}

以下のプロトコールにてFEL照射及び評価を行った。 (1)顕微赤外分光光度計 (FT-IR) (Horiba: FT-520)により FEL 照射前の赤外吸収スペクトルを測定し, サンプル表面 のコレステロール蓄積部位を探索する. FT-IRは赤外透 過面が $100 \mu \mathrm{m} \times 100 \mu \mathrm{m}$ の正方形で，透過法により測定 を行った。

(2)FELをコレステロール蓄積部位に照射する.FEL波長 は，コレステロールエステル中のエステル結合の赤外 吸収波長 $5.75 \mu \mathrm{m}$ と, エステル結合に吸収のない波長で 比較対照するため, 生体組織の蛋白質中に多く見られ るアミドI結合の赤外吸収波長 $6.06 \mu \mathrm{m}$ を使用した. FEL

\section{(b) Region of arteriosclerosis}

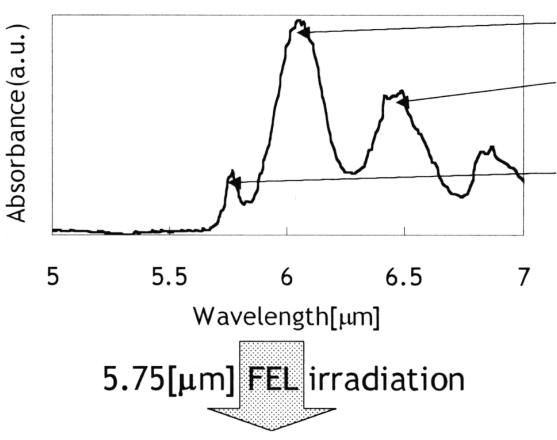

Amido I

Amido II

Cholesterol ester

(a) Normal

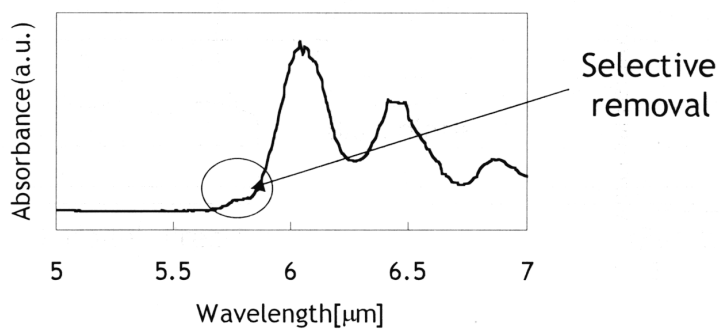

Fig. 2 Infrared absorption spectra of the human carotid artery. (a) Normal parts. (b) Cholesterol accumulated in the regions of arteriosclerosis.
照射実験系をFig. 3に, FEL照射条件をTable 1に示す. (3)FEL照射後のコレステロール蓄積部位の赤外吸収スペク トルをFT-IRにより測定し，照射前後を比較することで FEL照射効果を評価した。

\section{3. 実験結果}

$3.16 .06 \mu \mathrm{mFEL}$ 照射結果

Fig. 4(a)に波長 $6.06 \mu \mathrm{m}$, 平均パワー $5 \mathrm{~mW}$ (パワー密度 $\left.15.9 \mathrm{~W} / \mathrm{cm}^{2}\right)$, 照射時間 $180 \mathrm{sec}$ のFEL照射前後の赤外吸収 スペクトルを示す.

$6.06 \mu \mathrm{m}$ のFELを照射した場合，アミドIの赤外吸収スペ クトルピーク值 $(6.06 \mu \mathrm{m}$ 付近) は 44\%低減し, コレステ ロールエステルの赤外吸収スペクトルピーク值 $(5.75 \mu \mathrm{m}$ 付 近) は〜27\%低減した。このコレステロールエステルの赤 外吸収スペクトルピークの減少は, FEL照射による組織変 性の影響と, FEL照射点のサンプル量減少起因の赤外吸収 スペクトルの縮小であると考えられる。しかし, FEL照射 波長 $6.06 \mu \mathrm{m}$, 平均パワー $5 \mathrm{~mW}$ (パワー密度 $15.9 \mathrm{~W} / \mathrm{cm}^{2}$ ) 付 近の照射条件では, 組織の変性は小さく, 照射時間の依 存性は少ないと考えられる。また， $6.06 \mu \mathrm{m}$ のEEL照射で は，コレステロールエステルの選択的除去は困難である いうことが示された。

\section{2 $5.75 \mu \mathrm{mFEL}$ 照射結果}

Fig. 4 (b) に波長 $5.75 \mu \mathrm{m}$, 平均パワー $5 \mathrm{~mW}$ (パワー密度 $15.9 \mathrm{~W} / \mathrm{cm}^{2}$ )，照射時間 $180 \mathrm{sec}$, Fig. 4 (c) に波長 $5.75 \mu \mathrm{m}$, 平均パワー $6.5 \mathrm{~mW}$ (パワー密度 $9.19 \mathrm{~W} / \mathrm{cm}^{2}$ ), 照射時間 30 sec, Fig. 4(d)に波長 $5.75 \mu \mathrm{m}$, 平均パワー7.8 mW(パワー 密度 $\left.69 \mathrm{~W} / \mathrm{cm}^{2}\right)$, 照射時間 $60 \mathrm{sec} の F E L$ 照射前後の赤外吸

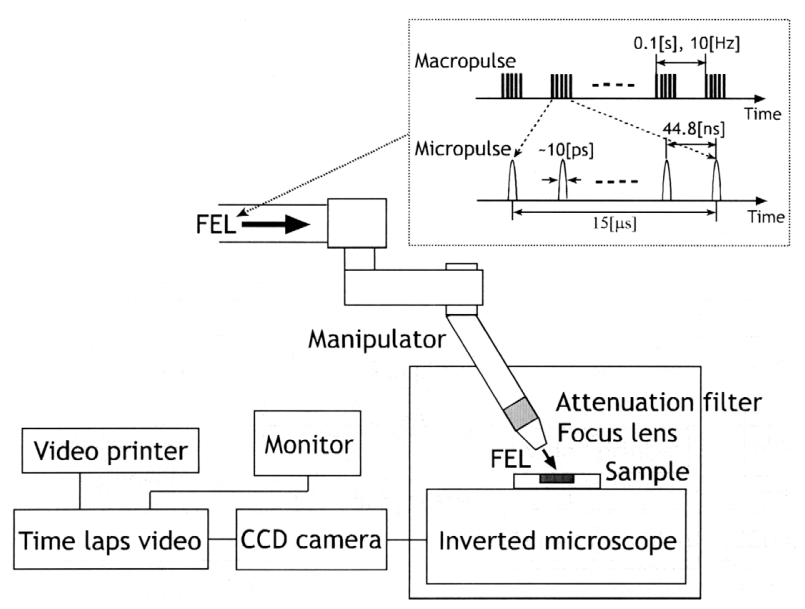

Fig. 3 FEL irradiation system and pulse structure of FEL.

Table1 FEL irradiation conditions.

\begin{tabular}{cccccc}
\hline $\begin{array}{c}\text { Wavelength } \\
{[\mu \mathrm{m}]}\end{array}$ & $\begin{array}{c}\text { Average Power } \\
{[\mathrm{mW}]}\end{array}$ & $\begin{array}{c}\text { Irradiation } \\
\text { Area }\left[\mathrm{cm}^{2}\right]\end{array}$ & $\begin{array}{c}\text { Power Density } \\
{\left[\mathrm{W} / \mathrm{cm}^{2}\right]}\end{array}$ & $\begin{array}{c}\text { Irradiation } \\
\text { Time [sec] }\end{array}$ & Fig. Number \\
\hline \hline 6.06 & 5 & $3.14 \times 10^{-4}$ & 15.9 & 180 & Fig.4(a) \\
& 6.5 & $7.07 \times 10^{-4}$ & 15.9 & 180 & Fig. 4(b) \\
5.75 & 7.8 & $1.13 \times 10^{-4}$ & 6.19 & 30 & Fig.4(c) \\
& & & & 60 & Fig.4(d) \\
\hline
\end{tabular}


(a)

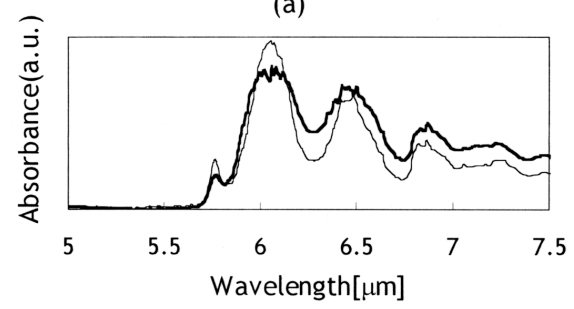

(b)

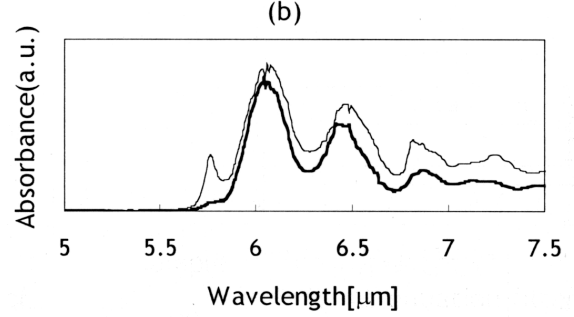

(c)

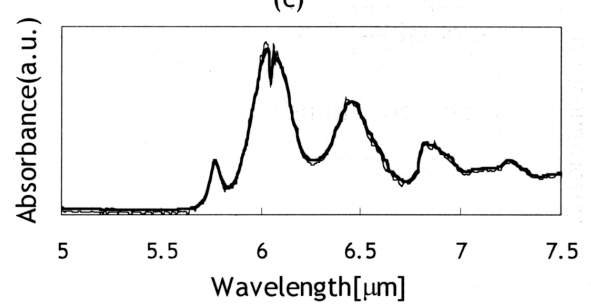

(d)

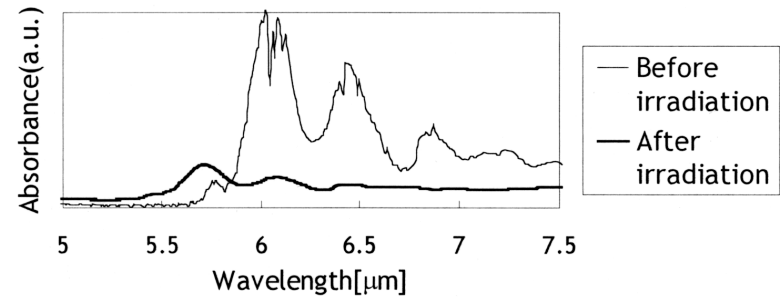

Fig. 4 Infrared absorption spectra before and after irradiation of FEL. There is a mention of FEL irradiation conditions (Table 1).

収スペクトルを示す。

パワー密度 $15.9 \mathrm{~W} / \mathrm{cm}^{2}$ でFELを照射した場合，コレステ ロールエステルの赤外吸収スペクトルピーク值 $(5.75 \mu \mathrm{m}$ 付 近)の低減，消失が見られた。照射時間 $30 \mathrm{sec}$ では $83 \%$, $60 \mathrm{sec}$ で $88 \%$ ，180 secのときは90\%で，Fig. 4(b)よりコレ ステロールエステルの赤外吸収スペクトルピークが消失 していると捉えることができた。 また，照射時間 $30 〜 180$ $\sec$ の, 計測した赤外吸収スペクトルのどの波長域におい ても, スペクトル形状の顕著な变化は観察されず, 赤外 吸収スペクトルは相似的变化であった。照射時間 $180 \mathrm{sec}$ (Fig. 4(b))のとき, コレステロールエステル以外の赤外吸 収スペクトルピーク值の低減率は10３9\%であった。

FEL180 sec照射後のサンプル表面の画像をFig. 5 (a)に示 す. Fig. 5(a)から，FEL照射後もサンプルに光学顕微鏡下 で変化が観察されなかったことから, 正常組織への影響 は少ないと考えられる。

したがって, FEL照射波長 $5.75 \mu \mathrm{m}$, 平均パワー5 $\mathrm{mW}$ (パワー密度 $15.9 \mathrm{~W} / \mathrm{cm}^{2}$ ), 照射時間 30〜180 sec付近の照 射条件では，赤外分光測定からアミドI，アミドIIの赤外 吸収に変化を与えず，コレステロールエステルを選択的
FEL irradiation area

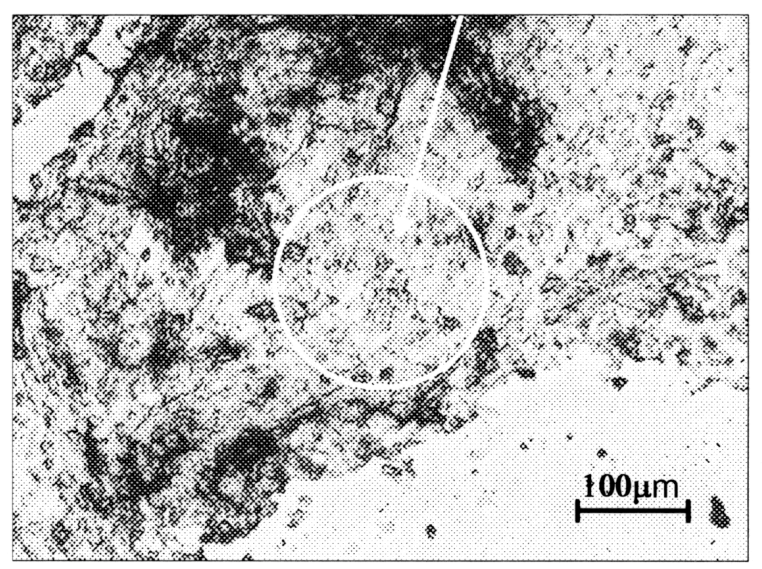

(a)

FEL irradiation trace by excessive power density

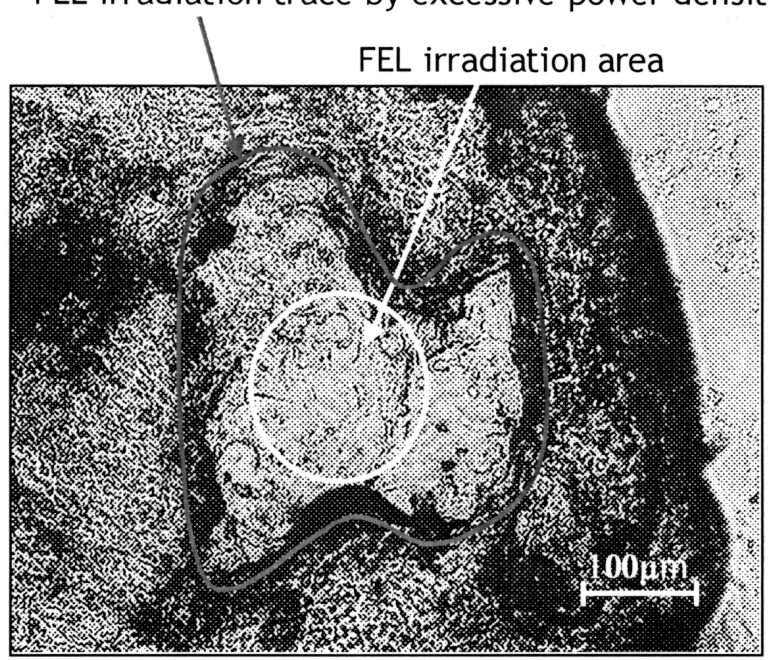

(b)

Fig. 5 Surface of the sample (tunica intima of the blood vessel) after irradiation of $5.75 \mu \mathrm{m}$ FEL. (a) Power density $15.9 \mathrm{~W} / \mathrm{cm}^{2}$, irradiation time $180 \mathrm{sec}$. There is no irradiation trace. (b) Power density $69 \mathrm{~W} / \mathrm{cm}^{2}$, irradiation time $60 \mathrm{sec}$. The edge of irradiation trace is carbonized.

に除去できるということが示された。

パワー密度 $9.19 \mathrm{~W} / \mathrm{cm}^{2}$ でFELを照射した場合, Fig. 3(c) のようにコレステロールエステルの赤外吸収スペクトル ピーク值の低減, 消失は見られなかった。照射時間 60 , $180 \mathrm{sec}$ ときも同様のスペクトルが得られた.

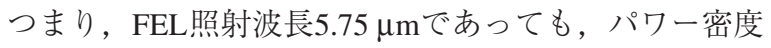
$9.19 \mathrm{~W} / \mathrm{cm}^{2}$ の場合はコレステロールエステルが除去されな いことが示唆された。

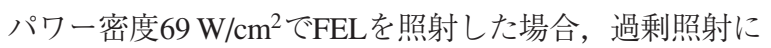
よる組織の変性によって, サンプル表面の照射跡を観察 した. 照射後, コレステロールエステルのピークは消失 した(Fig. 4(d))が，照射点のサンプル量の減少によりスペ クトル高が低く平滑になった。 また， $5.68 \mu \mathrm{m}$ 付近になだ らかなスペクトルピークが観測された. FEL $60 \mathrm{sec}$ 照射後 のサンプル表面の画像をFig. 5(b)に示す. 


\section{4. 考察}

粥状動脈硬化病変は, いわゆるソフトプラークと呼ば れる脂質に富んだ粥状成分と, ハードプラークと呼ばれ るコラーゲンに富んだ硬化組織成分とで構成され，ソフ トプラークにはコラーゲンや血管成分のない細胞外脂質 に富んだアテロームコアが存在する。プラークの柔らか さは, エステル化された細胞外脂質の比率により決定さ れる。ソフトプラークは破裂・崩壊による血管閉塞, あ るいはかん流組織の虚血性障害を起こしやすいものとさ れ臨床上重要であり, また血管内治療(経皮的血管拡張術 あるいはステント留置術)においては, プラークの内容物 が血管内に押し出され, 重篤な合併症である塞栓症を起 こしやすいものとされ, 血管内治療の適応は否定的で あった。赤外FELを用いる本法によりコレステロールの選 択的除去がカテーテル治療により可能であれば，血管内 治療はより安全に施行可能となると考えられる.

これまでに, オレイン酸コレステリル単体の脱水した 薄膜をサンプルとした，コレステロールエステルの選択 的除去や選択的分子振動励起効果の研究がなされてき た1-7).これらの結果から波長5.75 $\mu \mathrm{m}$ のFELによるオレイ ン酸コレステリル薄膜のコレステロールエステルの最適 な選択的除去条件はパワー密度 4.5 7.5 W/ $\mathrm{cm}^{2}$ であると報 告されている5).

今回, ヒトの䅡動脈内膜粥状動脈硬化部位中のコレス

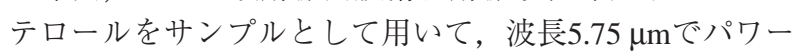
密度 $15.9 \mathrm{~W} / \mathrm{cm}^{2}$ のFEL照射により, コレステロールエステ ルのみが選択的に除去できることがFT-IRの赤外吸収スぺ クトルから示された. また, FEL照射後の試料表面に光学 顕微鏡下での血管内膜などの形態学的な変化は認められ なかった．照射による正常組織への影響は無視できるレ ベルまで抑えられたものと考えられ，今後さらに動物モ デルによる急性実験あるいは慢性実験により安全性の確 認を進める予定である.

Fig. 6に，従来のオレイン酸コレステリルで観測された コレステロールの選択的除去で報告されている条件1,5) と, 今回のヒトの澒動脈涫状動脈硬化部位で観測された ものの, 赤外吸収スペクトルの吸光度から算出したコレ ステロール分解率のパワー密度依存性を示す。

Fig. 6より, オレイン酸コレステリル単体のコレステ ロールエステルの選択的除去は, パワー密度 $1 \sim 10 \mathrm{~W} / \mathrm{cm}^{2}$

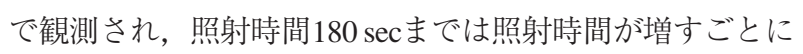
コレステロールの分解率も大きくなった. ヒトの䅡動脈 䉼状動脈硬化部位のコレステロールエステルの選択的除 去は，パワー密度 $15.9 \mathrm{~W} / \mathrm{cm}^{2}$ と $69 \mathrm{~W} / \mathrm{cm}^{2} て ゙$ 観測され，パ ワー密度 $15.9 \mathrm{~W} / \mathrm{cm}^{2}$ のとき照射時間が増すごとにコレス テロールの分解率も大きくなり, 照射時間 $180 \mathrm{sec}$ で分解率 は90\%に達した。

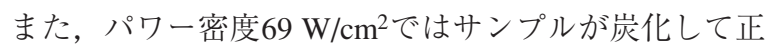

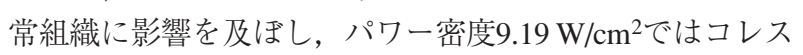
テロールエステルを除去できないことから，コレステ ロールエステルの選択的除去の最適条件は, これらのパ ワー密度の間で $15.9 \mathrm{~W} / \mathrm{cm}^{2}$ の前後であることが示された。

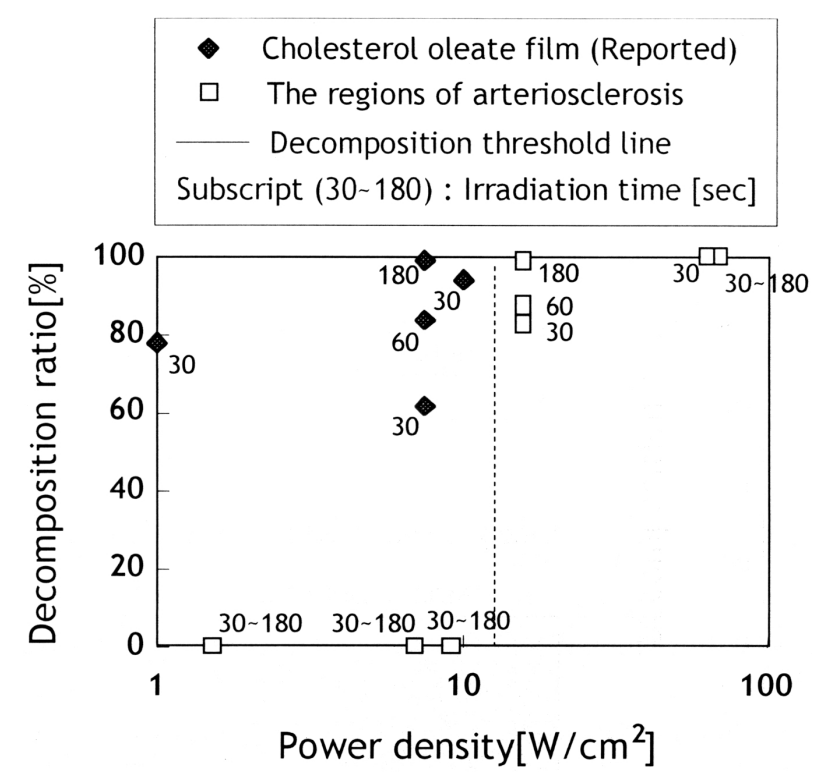

Fig. 6 Power density dependence of cholesterol decomposition ratio.

ヒトの韻動脈内コレステロールエステルのパワー密度を 変数とした選択的除去条件がオレイン酸コレステリルの ものより高いのは，ヒトの血管細胞を構成する水や蛋白 質の影響や，切り出した試料の表面の形状や厚さによる ものと考えられる.

FEL過剩照射時 (パワー密度 $69 \mathrm{~W} / \mathrm{cm}^{2}$ ) に5.68 $\mu \mathrm{m}$ 付近に なだらかなスペクトルピークが観測されたが，これはサ ンプルを構成する蛋白質やコレステロールエステルが炭 化したことにより, 分子間結合の形態の変化によって赤 外吸収スペクトルのピークが高波数側にシフトしたもの と考えられる。この現象の詳細は, コレステロールの選 択的除去の基礎過程として安全性・効率上重要であるた め，今後詳細を明らかにしなければならない。

FEL照射によるサンプル量減少起因の赤外吸収スペクト ルの相似的縮小 (Fig. 4 (a) (b) (d))が観察されたが，これは 以下のようなメカニズムによるものであると考えられ る. (1)高ピークパワー $\left(10^{8} \sim 10^{9} \mathrm{~W} / \mathrm{cm}^{2}\right)$ かつ短パルス ( psec)のFELがサンプル表面に入射することによって，多 数の光子が短時間に吸収され, 特定の分子振動が励起さ れる. (2)1つの振動モードに集中した振動エネルギーは, まず分子内に緩和し, 分子内の熱エネルギーに変換され る. (3)多くの熱エネルギーを得た最表面の分子が, 分子 間の結合を断ち切って蒸散する4,5).

この蒸散は, 熱エネルギーが深さ方向に伝搬し温度が 平均化するよりも早い過程であるため, FEL照射時にサン プル表面で局所的に生じる。従って，通常の加熱実験で は観察されず，パルスレーザーであるFELの照射によって のみ観察される ${ }^{4,5)}$.

\section{5. おわりに}

波長 $5.75 \mu \mathrm{m}$ (パワー密度 $15.9 \mathrm{~W} / \mathrm{cm}^{2}$ )の赤外自由電子 レーザーを, ヒトの動脈内䉼状動脈硬化部位 (コレステ 
ロール蓄積部位)に照射することにより, 動脈内膜正常組 織の損傷を抑え，選択的にコレステロールを除去できる ことを初めて示した. しかし, 本研究のように生体試料 をサンプルとした計測データはばらつきが大きいため, サンプル数と計測回数を増やして, 検討を重ねなければ ならない. そのため, 今後は, データのサンプル依存性 を考慮した，コレステロールの選択的除去の最適条件を 詳細化することや, 正常組織への影響を検討する等, 医 療応用上重要となってくる低侵襲性の定量的分析を進め る必要がある。

\section{謝 辞}

本研究に対し多くの助言を戴いた, 大阪大学大学院工 学研究科電子情報エネルギー工学専攻博士後期課程在籍 の深見裕子氏に深く感謝いたします。

\section{参考文献}

1）粟津 邦男，永井 昭夫，会沢 勝夫：レーザー研究 26 (1998) 369.

2) K. Awazu, A. Nagai, and K. Aizawa: Lasers in Surgery and Medicine 23 (1998) 233.

3）深見裕子, 前田佳均, 粟津 邦男：日本レーザー医学会誌 19 (1998) 123.

4）媣見 裕子，粟津 邦男：レーザー研究 27 (1999) 840.

5) 深見裕子，粟津邦男：レーザー研究 28 (2000) 695.

6) K. Awazu and Y. Fukami: Nucl. Instrum. Meth. Phys. Res. A 475 (2001) 650.

7) K. Awazu and Y. Fukami: Rev. Sci. Instrum. 72 (2001) 2239.

8）堀口 博：赤外吸光図説総覧（三共出版，1993）224, 269. 